\title{
Zircon fission-track dating of granites from the Vepor-Gemer Belt (Western Carpathians): constraints for the Early Alpine exhumation history
}

\author{
Dušan PLAŠIENKA ${ }^{1}$, Igor BROSKA ${ }^{*}$, Dana KISSOVÁ2, István DUNKL ${ }^{3}$ \\ ${ }^{1}$ Department of Geology and Palaeontology, Comenius University, Mlynská dolina G, 84215 Bratislava, Slovakia \\ ${ }^{2}$ Geological Institute, Slovak Academy of Sciences, Dúbravská cesta 9, 84005 Bratislava, Slovakia; igor.broska@savba.sk \\ ${ }^{3}$ Geoscience Center Götingen, Goldschmidtstrasse 3, D-37077 Göttingen, Germany \\ ${ }^{*}$ Corresponding author
}

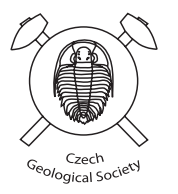

\begin{abstract}
We present new zircon fission-track (ZFT) data from Variscan granitoid bodies in the Veporic (footwall unit) and Gemeric (hangingwall unit) thick-skinned nappe sheets of the Central Western Carpathians. All samples show Late Cretaceous to earliest Paleogene cooling ZFT ages, which contribute to constraining the low-temperature exhumation history of the Vepor-Gemer Belt. Four granite samples from the western part of the Gemericum near the contact with the underlying Veporicum provided central ZFT ages between $70.4 \pm 5.4$ and $74.7 \pm 5.6 \mathrm{Ma}$. One sample from this area shows an older age of $87.7 \pm 5.9 \mathrm{Ma}$, possibly owing to its higher structural position. One remoter sample from the SE part of the Gemeric Unit has $61.7 \pm 3.4$ Ma central ZFT age, which probably reflects exhumation associated with a younger compressional tectonic event in that area. One sample from the centre of the Veporic metamorphic core complex yielded a cooling age $64.9 \pm 4.8 \mathrm{Ma}$. However, most of these samples exhibit an internal age scatter pointing to complex cooling and exhumation history influenced by a slow passage through the zircon partial annealing zone and/or reheating brought about by the Cretaceous Rochovce granite intrusion. In spite of this, the acquired ages generally match the exhumation trend of the Veporic metamorphic core complex.
\end{abstract}

Keywords: fission-track zircon data, exhumation, granites, Gemeric Unit, Veporic Unit, Western Carpathians Received: 6 February 2007; accepted 29 May 2007; handling editor: V. Janoušek

\section{Introduction}

Zircon and apatite fission-track analyses (ZFT and AFT, respectively) are widely applied in various geological settings because they represent a tool for constraining the time elapsed after these minerals crossed annealing or "closure" temperature, above which the tracks are healed. Although chemical composition, crystal structure and pressure show influence to annealing of tracks (Carlson 1990; Barbarand et al. 2003), the fission tracks are often interpreted more simplistically. In comparison to apatite, the mechanism of zircon annealing is not yet fully understood and recent studies suggest a wide range of temperatures for the zircon annealing $\left(200-310^{\circ} \mathrm{C}\right.$ : Tagami et al. 1998). In this study we adopted a commonly accepted effective closure temperature of $240 \pm 50^{\circ} \mathrm{C}$ (Hurford and Green 1983; Hurford 1986) corresponding to the upper crustal depths at a normal thermal gradient. The above temperature ranges are widely used to define the zircon partial annealing zone (PAZ). When reheated to PAZ, the existing fission tracks are progressively shortened and above a given temperature they disappear completely.

Existing ZFT and AFT data from the Western Carpathian crystalline basement indicate an earlier exhumation of the Vepor-Gemer domain in comparison to the Tatra-Fatra belt of "core mountains" (Král' 1977; Kováč et al. 1994; Danišík et al. 2004). According to these data, the Veporic domain started exhumation already during the Late Cretaceous, following the Palaeo-Alpine compression stage. At that time the Veporic Unit has been buried to the middle crustal depth (see Janák et al. 2001a) but within the period 90-55 Ma its depth decreased to about $5 \mathrm{~km}$ (AFT data, Král' 1977) at an exhumation rate 0.5-1 mm/a (estimated by Kováč et al. 1994). On the other hand, the Tatric crystalline basement reached this level considerably later, mainly in the period 35-20 Ma (Kováč et al. 1994). The AFT thermochronology used to constrain the burial and exhumation history of basement highs along the NW margin of the Pannonian basin resulted in different timing of exhumation in the Malé Karpaty and Tribeč Mts. on the one hand (44 to $35 \mathrm{Ma}$ ), and Považský Inovec (21 to $13 \mathrm{Ma}$ - Danišík et al. 2004) on the other. The oldest to date measured zircon FT ages from the Western Carpathians come from pebbles of granitoids from the Cretaceous "exotic" conglomerates of the Pieniny Klippen Belt (110-90 Ma; Kissová et al. 2005).

In this contribution we present and discuss new ZFT age data obtained from granites occurring mostly in the contact zone between the Gemeric and Veporic units in 
the southern Central Western Carpathian zones. Our results extend the thermochronological dataset of the area and fill the gap between the published ${ }^{40} \mathrm{Ar} /{ }^{39} \mathrm{Ar}$ ages (hornblende, muscovite, biotite, generally between 100 and $70 \mathrm{Ma}$ ) and AFT measurements (down to $50 \mathrm{Ma}$ ). We interpret these data in terms of extensional exhumation of the Veporic domain, by a mechanism similar to exhumation of the metamorphic core complexes. Samples from the hangingwall Gemeric Unit show significant dispersal of individual grain ages, but the calculated central ages follow the exhumation and cooling trend indicated by the other thermochronological data from the area. Consequently, we consider our data applicable for constraining low-temperature exhumation history of the Vepor-Gemer region.

\section{Geological setting}

The Vepor-Gemer Belt in southern part of the Central Western Carpathians is dominantly composed of basement complexes of the Veporic and Gemeric thickskinned thrust sheets (e.g. Plašienka et al. 1997). The Veporic basement comprises various, presumably Lower Paleozoic volcano-sedimentary complexes metamorphosed mostly under the amphibolite-facies conditions during the Variscan orogeny (e.g. Krist et al. 1992). These metamorphic complexes were intruded by several suites of Variscan granitoids constituting the extensive composite Vepor Pluton (e.g. Petrík and Kohút 1997; Petrík et al. 1998; Broska and Uher 2001). Permian post-orogenic history was dominated by reheating, rifting, uplift and erosion, as recorded by signs of HT/LP metamorphism (Jeřábek et al. 2007), A-type granitic intrusions and sedimentation of continental red-beds in associated grabens. The Mesozoic cover consists only of Triassic sandstones and carbonates in the southern Veporic Unit. During the Palaeo-Alpine (Cretaceous) orogeny, the Veporic basement and cover were overridden by the Gemeric basement/cover nappe sheet and underwent low- to medium-grade metamorphism and ductile deformation (e.g. Janák et al. 2001a). At the Veporic-Gemeric contact zone, a hidden subsurface Rochovce granitic body was revealed by drilling and proven to be the only known Cretaceous granite intrusion in the Western Carpathians (Hraško et al. 1999; Poller et al. 2001).

The deep burial of the Veporic Unit was for the first time indicated by Vrána (1964), who documented a significant metamorphic overprint at $450{ }^{\circ} \mathrm{C}$ during the Palaeo-Alpine orogeny. According to Vrána $(1966,1980)$, the newly-formed Alpine grossular from metagranitoids of the Veporides corresponds to Alpine garnets from High Tauern and Swiss Alps with a comparable metamorphic grade. Vrána (1. c.) suggested more than $10 \mathrm{~km}$ of overburden above the Veporic Unit and explained it by obduction of the Tatric and Gemeric units over the Veporic. Later on the Vrána's estimates of metamorphic grade in the Veporic Unit were fully confirmed and established to $c$. $500-800 \mathrm{MPa}$ at $400-550^{\circ} \mathrm{C}$ (Vozárová 1990; Méres and Hovorka 1991a, b) at lower to middle pressure conditions (Kováčik et al. 1996). According to Plašienka et al. (1999) and Janák et al. (2001a) the Alpine metamorphic assemblages in the Veporic crystalline basement indicate conditions from $500^{\circ} \mathrm{C}$ and $700-800$ $\mathrm{MPa}$ to $620^{\circ} \mathrm{C}$ and $900-1000 \mathrm{MPa}$, i.e. a metamorphic gradient from the greenschist to amphibolite facies. The tectonic interpretation of these authors assumes that the Veporic Unit has evolved as a metamorphic core complex during the Cretaceous growth of the Western Carpathian orogenic wedge. In this sense metamorphism was related to collisional crustal shortening and stacking, following closure of the southerly located Meliata Ocean. Subsequent exhumation was accomplished by orogen-parallel extension and unroofing in an overall compressive regime (Plašienka et al. 1999). The master low-angle detachment fault corresponds to the present Veporic/Gemeric contact zone (the so-called Lubeník-Margecany line), which is a reactivated original thrust plane (see Fig. 4).

The Gemeric thrust sheet is composed of mostly lowgrade pre-Alpine basement and its Pennsylvanian-Triassic sedimentary cover. The basement includes Lower Palaeozoic volcano-sedimentary formations (Gelnica, Rakovec and high-grade Klátov groups) intruded by fairly small bodies of post-orogenic Permian to Early Triassic granites of two basic types (Uher and Broska 1996; Finger and Broska 1999; Broska et al. 2001; Poller et al. 2002): more widespread specialized (tin-bearing) S-type granites (Betliar, Hnilec, Dlhá dolina and Poproč) as well as the single A-type granitic body near Turčok.

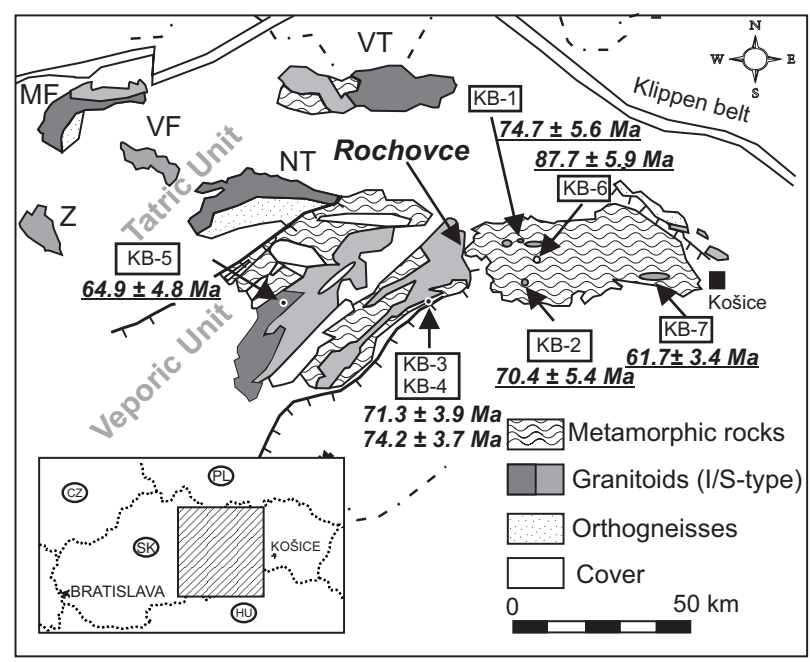

Fig. 1 Geological sketch of the Western Carpathians crystalline basement and positions of the investigated samples. 
The northernmost part of the Gemeric Zone is composed of Mississippian rocks (Ochtiná Group). Pennsylvanian to Scythian cover is composed of various clastic sediments dominated by Permian red-beds. Except for strong deformation and penetrative cleavages, the Alpine metamorphic overprint is rather low, reaching the greenschist facies in the Gemeric basement.

The Gemeric Superunit is overridden by nappe outliers of the Meliatic Superunit (Bôrka nappe) and the Silicic cover nappe system. The Bôrka nappe includes TriassicJurassic oceanic complexes, including ophiolites, which suffered a Late Jurassic blueschist-facies metamorphic overprint (Maluski et al. 1993; Dallmeyer et al. 1996, 2005; Faryad and Henjes-Kunst 1997).

\section{Sample locations and their characteristics}

Granites chosen for ZFT dating were taken from the main granite bodies in the Gemeric Unit, and one sample from the Veporic Sihla tonalites. Geographic and geological position of samples is shown in Fig. 1.

The granites from the Gemeric Unit (KB-1, 2, 6, 7) differ from all other granite groups in the Western Carpathians by their Sn-Mo-B-F specialization and additional $\mathrm{Nb}-\mathrm{Ta}-\mathrm{W}-$ rich mineralization. Therefore, they are designated as specialized S-type granitoids represented by biotite-muscovite to muscovite leucogranites, albite-, microcline, \pm topaz-bearing granites and/or rare granite porphyries (Uher and Broska 1996; Broska and Uher 2001). They show Permian-Early Triassic intrusion ages, which were obtained by zircon single grain $\mathrm{U}-\mathrm{Pb}$ isotopic analyses (Poller et al. 2002), by monazite CHIME dating (Finger and Broska 1999), Re-Os molybdenite dating (Kohút et al. 2004; Kohút and Stein 2005) and earlier Rb-Sr WR and mineral isochrons (Cambel et al. 1989). These granites originated from a mature continental metasedimentary feldspar- and muscovite-rich protolith (Petrík and Kohút 1997). The partial melting was probably induced by heating of the lower crust due to rifting processes during the Permian-Early Triassic period (Broska and Uher 2001). Sample KB-1 was taken from the Hnilec body, KB2 from the Betliar granite porphyry and KB-6 (borehole DD-3 from the Dlhá dolina valley) is an example of the most evolved granite emplaced to the shallowest crustal levels due its high primary contents of volatiles.

The Turčok granite $(\mathrm{KB}-3,4)$ is a representative of the A-type granites, which are Permian in age (Putiš et al. 2006) and were probably generated along a continental strike-slip zone. It is located along the Hrádok Fault Zone near the Veporic-Gemeric contact. The Turčok granite is strongly tectonically deformed biotitic granite with specific A-type chemistry as well as accessory mineral assemblage (Uher and Gregor 1992). This granite is enriched in zircon, apatite, allanite, magnetite, tourmaline and pyrite.

The Sihla tonalite (KB-5), as the most prominent Veporic granitoid rock, belongs to the post-tectonic I-type granite suite, which according to conventional zircon dating shows Late Carboniferous age (Bibikova et al. 1990). Microgranular enclaves, a conspicuous feature of the Sihla granitoids, indicate their origin in the lower crustal conditions above a zone of asthenosphere upwelling, where mixing of silicic and basic magmas was commonplace (Broska and Uher 2001).

\section{Analytical procedure}

Zircons were obtained by a routine separation method with crushing and sieving of approximately $6 \mathrm{~kg}$ of investigated rocks. The concentration of accessory minerals was done on Wilfley shaking table and the resulting heavy fraction was purified using heavy liquid (bromophorm). Finally, after magnetic separation, zircon grains were hand-picked and mounted in Teflon for the cathodoluminescence (CL) analysis and for FT dating.

Formation of fission tracks is described as a decay of an ${ }^{238} \mathrm{U}$ atom into two highly charged particles, which travel through the crystal lattice creating a linear zone of damage called fission track (Fleischer et al. 1975; Wagner and Van den Haute 1992). Chemical etching enlarges these tracks in minerals. Our zircon grains were etched in eutectic melt of $\mathrm{KOH}$ and $\mathrm{NaOH}$ for 31-54 hours at $200{ }^{\circ} \mathrm{C}$ and spontaneous tracks in zircons were counted under the optical microscope. After etching we prepared the sample for the irradiation. Sample preparation for irradiation included mounting of the zircon crystals to the Teflon PFA, polishing and etching. We were using grinding paper (1200 and 2500) for polishing and polishing diamond suspensions of different grain size $(9 \mu \mathrm{m}$, $3 \mu \mathrm{m}, 1 \mu \mathrm{m})$. Every mount was covered with flakes of low-U muscovite from India, packed using foam, polyethylene and parafilm and irradiated at the TRIGA nuclear reactor (Oregon, USA). Standard of known age (Fish Canyon Tuff, Tardree Rhyolite - Hurford 1998) and glass dosimeters with known uranium concentration $\mathrm{CN} 2$ were included in the package for irradiation and used for the calculation of a $\zeta$-value (zeta) - Hurford and Green (1983), Hurford (1998). The calculated personal $\zeta$-value is $122.4 \pm 3.3$. All fission tracks in age standards and in samples were counted using the same microscope setup (Zeiss Axioscope, objective with $1000 \times$ magnification, using immersion oil). The ages were calculated using software TrackKey (Dunkl 2002). 


\section{Results}

\subsection{Zircon characterization}

Zircons are only very slightly metamictized in all investigated samples. Their colour is pink or hyacinth with elongation usually exceeding 2-3.

The Sihla granite zircons (KB-5) show a very fine internal zoning indicating a prolonged crystallization. There are only slight changes in morphology from cores to rims with relatively limited diffusion features inside the crystals (Fig. 2a). However, proportion of inherited cores is rather high. According to the Pupin's classification (1980), the $S_{12}$ zircon subtype prevails.

The Turčok granite (KB-3, KB-4), as a representative of the A-type granites, has high $\mathrm{P}$ and $\mathrm{D}$ subtypes of zircons reflecting origin from dry and hot magmas (Uher and Gregor 1992). These zircon subtypes strongly prevail over the other $(70$ vol. \%). Although the diffusion or element redistribution within the zircon grains is relatively high, zircons have been dated (Fig. 2b).

Primary zircons from the Gemeric S-type granites (KB-1, KB-2, KB-6, KB-7) are mainly $\mathrm{S}_{8}$ subtypes, secondary or late magmatic belong to the $\mathrm{G}_{1}$ subtype. The latter fraction forms about $15-20$ vol. \% of the total zircon population. These late-stage zircons show also different composition (higher contents of $\mathrm{P}, \mathrm{Y}$ and $\mathrm{Hf}$ ). The CL images often show primary oscillatory zoning of zircons, but inherited cores are usually not apparent. Rarely some crystal cores have a morphology close to the higher temperature origin or high-temperature D zircon subtypes (Fig. 2c). Fluid interaction resulting in diffusion texture of zircons is present relatively often, especially in the Dlhá dolina granites (KB-6), where rocks were strongly affected by a fluid activity (Fig. 2d). Zircons from the Betliar granite porphyry (KB-2) are characterized by a complicated growth history. Older zircon cores crystallized relatively rapidly in (highly) alkaline environment ( $G$ type), later zircons overgrew cores at higher temperatures to the final $\mathrm{S}_{3}$ subtype (Fig. 2e). Signs of the alkaline activity indicate possibility of a partial zircon dissolution. This process probably occurred at the late stage of the granite evolution and is recorded by smooth edges of some inner faces on the CL images (Fig. 2f). Dissolution of zircon is observable also on the grain surfaces.

\subsection{Zircon fission-track results}

Zircon fission-track ages (ZFT) were determined on 7 granite samples and most of them passed the chi-square test. The obtained ZFT were reported as central ages in the range between $61.7 \pm 3.4$ and $87.7 \pm 5.9 \mathrm{Ma}$ (Tab. 1 ). Radial plots portray the dispersion of data and refer to the mean values of the measured ages (Fig. 3). However, all samples show either a scatter of ages obtained from individual grains, or the number of measured grains is too low for reliable conclusions. Consequently, the geological meaning of the obtained age data might be questionable. Most probably the measured samples represent apparent or mixed ages of rocks that experienced a complex thermal history.

\section{Discussion}

According to the regional tectonic interpretation of Plašienka et al. (1999) and Janák et al. (2001a), the Vepor-Gemer area represents an Alpine metamorphic terrain that was exhumed as a core complex during the Late Cretaceous. The Veporic basement/cover Superunit occurs in the footwall of a low-angle detachment fault and suffered a greenschist- to lower amphibolite-facies metamorphic overprint. In contrast, the hangingwall Gemeric basement/cover Superunit experienced only greenschist to very low-grade Alpine metamorphism. Nevertheless, P-T metamorphic conditions in both units were well above the ZFT closure temperature, especially

Tab. 1 Zircon fission-track results measured on granitoid samples from the Gemeric and Veporic superunits.

\begin{tabular}{|c|c|c|c|c|c|c|c|c|c|c|c|c|}
\hline \multirow[t]{2}{*}{ Localities } & \multirow[t]{2}{*}{ Code } & \multirow[t]{2}{*}{ Petrography } & \multirow[t]{2}{*}{ Cryst. } & \multicolumn{2}{|c|}{ Spontaneous } & \multicolumn{2}{|c|}{ Induced } & \multicolumn{2}{|c|}{ Dosimeter } & \multirow{2}{*}{$\begin{array}{c}P \\
(\%) \\
\end{array}$} & \multirow[t]{2}{*}{ Disp. } & FT age* \\
\hline & & & & ps & (Ns) & $\rho \mathbf{i}$ & (Ni) & $\rho d$ & (Nd) & & & $(\mathrm{Ma} \pm 1 \sigma)$ \\
\hline Hnilec-Delava & KB-1 & granite (Ss-type) & 16 & 59.3 & 490 & 45.2 & 373 & 9.35 & 6008 & 67.30 & 0.01 & $74.7 \pm 5.6$ \\
\hline Betliar & KB-2 & granite (Ss-type) & 14 & 107.8 & 1420 & 88.4 & 1165 & 9.39 & 6008 & 0.00 & 0.21 & $70.4 \pm 5.4$ \\
\hline Turčok & KB-3 & granite (A-type) & 24 & 116.6 & 1822 & 94.9 & 1483 & 9.59 & 6008 & 1.61 & 0.14 & $71.3 \pm 3.9$ \\
\hline Turčok & KB-4 & granite (A-type) & 32 & 129.1 & 2665 & 102.3 & 2111 & 9.64 & 6008 & 0.16 & 0.15 & $74.2 \pm 3.7$ \\
\hline Sihla & KB-5 & tonalite (I-type) & 13 & 90.8 & 473 & 79.1 & 412 & 9.29 & 6008 & 63.56 & 0.00 & $64.9 \pm 4.8$ \\
\hline Dlhá dolina DD-3 & KB-6 & granite (Ss-type) & 22 & 116.8 & 1355 & 75.2 & 872 & 9.24 & 6008 & 0.55 & 0.19 & $87.7 \pm 5.9$ \\
\hline Poproč & KB-7 & granite (Ss-type) & 30 & 82.6 & 1737 & 75.2 & 1582 & 9.15 & 6008 & 0.93 & 0.16 & $61.7 \pm 3.4$ \\
\hline
\end{tabular}

Note: track densities $(\rho)$ are as measured and are $\left(\times 10^{5} \mathrm{tr} / \mathrm{cm}^{2}\right)$; number of tracks counted $(N)$ shown in parentheses; P is probability of obtaining $\chi^{2}$ value for $n$ degree of greed (when $n=$ no crystals-1); zircon ages calculated using dosimeter glass CN_2 with $\zeta=122.4 \pm 3.3$ 

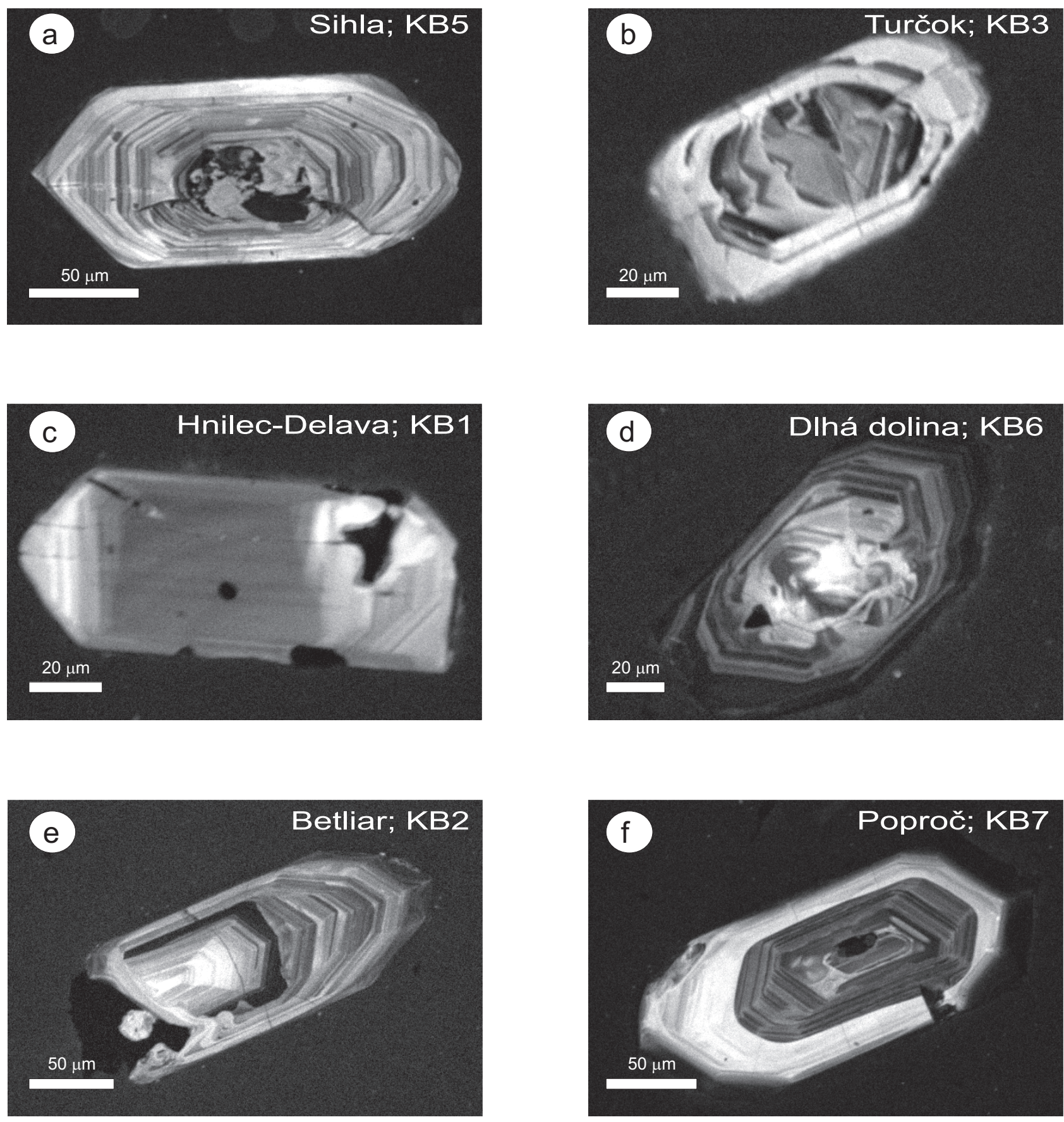

Fig. 2 Cathodoluminescence images of the selected investigated zircons. a - locality Tlstý Javor (Sihla I-type granite), example of zircon with inherited core and prolonged crystallization determined by the fine oscillatory zoning; $\mathbf{b}$ - Turčok (A-type granite), a high-temperature primary zircon of P or D-subtype attacked by corrosive fluids; $\mathbf{c}$ - Hnilec (specialized S-type granite), change of zircon morphology from high "D subtype" to lower temperature subtype; d - Dlhá dolina DD-3 (specialized S-type granite), internal zoning of the zircon strongly overprinted by fluids; e - Betliar (specialized S-type granite), magmatic zircon of G type rimmed by a new S3 stage phase; $\mathbf{f}$ - Poproč (specialized S-type granite), zircon crystal that shows effects of leaching during magmatic growth indicating a highly alkaline environment.

in the basement complexes that we are dealing with in this paper. Therefore we suppose that in spite of a large error included in our ZFT data they generally represent cooling ages, though clearly much influenced either by a long stay of studied rocks within the PAZ, or alternatively a part of them may have been affected by reheating to the PAZ later. In order to evaluate these hypotheses in a regional context, we first briefly review the Alpine geochronological data from the Veporic and Gemeric basement/cover complexes. 


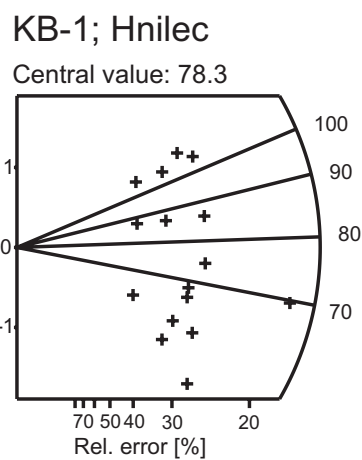

KB-5; Sihla

central value: 66.2

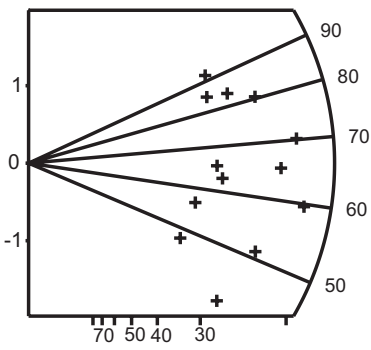

Rel. error [\%]
KB-2; Betliar

Central value: 72.6

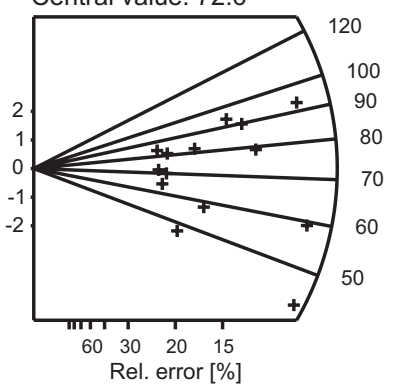

KB-6; DIhá dolina

Central value: 92.4

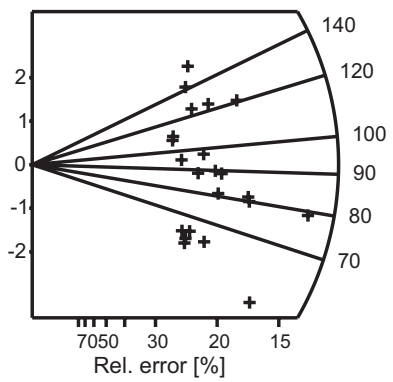

KB-3; Turčok

Central value: 73.3

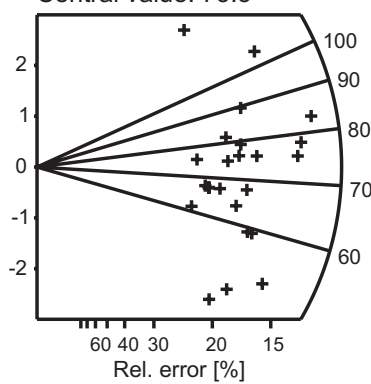

KB-7; Poproč

Central value: 64.7

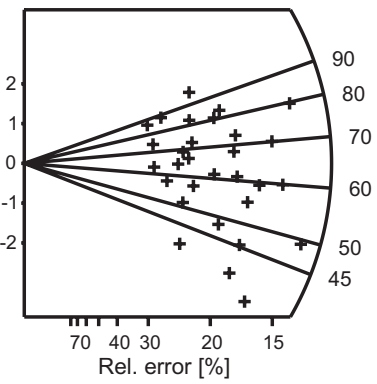

KB-4; Turčok

Central value: 76.5

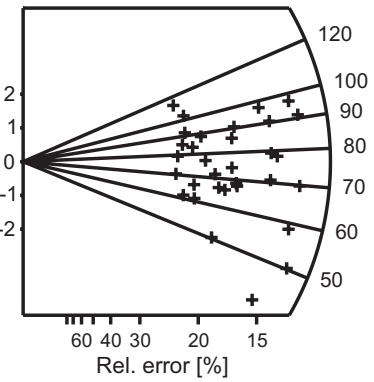

Fig. 3 Radial plots of investigated samples.

The oldest published age data about Alpine metamorphism in the Veporicum were presented by Kantor (1960), who reported K-Ar ages of newly-formed biotites in the range 107-75 Ma. Later on, Burchart et al. (1987) reassessed the Kantor's data and obtained an isochron age 94 $\pm 18 \mathrm{Ma}$ (see also Cambel et al. 1990). Modern ${ }^{40} \mathrm{Ar} /{ }^{39} \mathrm{Ar}$ dating techniques were firstly applied to mylonites within the Veporic basement by Maluski et al. (1993). Král' et al. (1996) reported discordant ${ }^{40} \mathrm{Ar} /{ }^{39} \mathrm{Ar}$ age spectra from the Veporic amphibolites showing a wide span from Variscan to Cretaceous ages pointing to mixed ages and/or excess argon, but ages of newly formed tschermakitic amphiboles between 115 and 105 Ma (Kováčik et al. 1996, 1997) probably have some geological meaning (thrusting event followed by onset of metamorphism). Koroknai et al. (2001) presented K-Ar amphibole age of $93.5 \pm 5.6$ Ma. Other age data probably indicating the thermal peak of Alpine metamorphism in the Veporic basement include Sm-Nd whole rock-garnet isochron $(108.8 \pm 5.6 \mathrm{Ma}$; Lupták et al. 2004) and electron microprobe dating of monazite (91 \pm 25 and $92 \pm 16 \mathrm{Ma}$; Janák et al. 2001b). Recently published monazite age data of a large sample set from the Veporic basement (Kováčik et al. 2005) exhibit a very wide span (from Precambrian to Cretaceous); the prevailing Alpine data range between 120 and $87 \mathrm{Ma}$ (with a significant error, though).

Comparably extensive dataset of ${ }^{40} \mathrm{Ar} /{ }^{39} \mathrm{Ar}$ ages comes from the Veporic white micas. Results of Maluski et al. (1993), Dallmeyer et al. (1996, 2006), Kováčik et al.
$(1996,1997)$ and Koroknai et al. (2001) indicate that the cooling ages concentrate between 90 and 80 Ma. Janák et al. (2001a) reported somehow younger ages (77 to $72 \mathrm{Ma}$ ) obtained by the UV laser probe technique. The low-temperature data are very scarce, the old published results of apatite FT dating of Veporic granites spread between $89 \pm 10$ and $53 \pm 7$ Ma (Král' 1977). Another data set comes from boreholes that penetrated the southernmost Veporic basement in northern Hungary - three samples provided ZFT ages in a narrow range between $77.5 \pm 3.5$ and $74.8 \pm 3.9 \mathrm{Ma}$, the presented AFT age was $51 \pm 3 \mathrm{Ma}$ (Koroknai et al. 2001).

During the exhumation and cooling, the contact zone between the Veporic and Gemeric superunits was influenced by a distinct thermal event - reheating due to the Rochovce granitic intrusion ( $82 \pm 1 \mathrm{Ma}$ : U-Pb zircon age according to Hraško et al. 1999, or $75.6 \pm 1.1$ Ma according to Poller et al. 2001). Thermal effect on the surrounding metasediments is revealed by a contact aureole with newly-formed HT/LP mineral assemblages indicating temperatures c. $500^{\circ} \mathrm{C}$ at mere $200 \mathrm{MPa}$ (Korikovsky et al. 1986; Vozárová 1990; Krist et al. 1992). These are clearly superimposed on the regional medium-pressure Barrovian-type associations.

$\mathrm{Few}{ }^{40} \mathrm{Ar} /{ }^{39} \mathrm{Ar}$ ages were published from the hangingwall Gemeric sheet. Amphiboles from the contact zone of the Permian Hnilec granites provided ages around $140 \mathrm{Ma}$ (Vozárová et al. 2000), the geological meaning of which is unclear (exhumation and cooling due to thrust- 
ing?). Only one Alpine white mica datum was reported by Dallmeyer et al. (1996, 2006): $105.8 \pm 0.3 \mathrm{Ma}$ from mylonitized Gemeric cover metasediments within a ductile shear zone at the Veporic/Gemeric contact, other measurements gave pre-Alpine ages. However, the Alpine metamorphic overprint in the Gemeric basement and cover still reached conditions of the lower greenschist facies (e.g. Varga 1973; Krist et al. 1992). Faryad and Dianiška (1989) described grossular outer rims of garnets from the Gemeric granites, which they considered to be most probably of Alpine age.

The above-listed data suggest that both Veporic and Gemeric granite bodies were heated well above the zircon PAZ during the Alpine (Cretaceous) metamorphism. Metamorphism culminated with maximum temperatures at c. $110-90 \mathrm{Ma}$ and cooled below the ${ }^{40} \mathrm{Ar} /{ }^{39} \mathrm{Ar}$ blocking temperature in white micas mostly between 90 to $80 \mathrm{Ma}$ ago. Consequently, the rocks should have passed the zircon PAZ later than $80 \mathrm{Ma}$ and, assuming a "smooth" exhumation/cooling trend, probably later than $70 \mathrm{Ma}$ ago.
Despite the low reliability due to the age dispersal of individual grains, our samples generally follow this expected trend. The only exception is KB-6 (Gemeric Dlhá dolina granite), which provided the central age 87.7 $\pm 5.9 \mathrm{Ma}$ (Fig. 1). The reason may be the high structural position of this granite body within the hangingwall Gemeric sheet, i.e. its earlier cooling and exhumation. Originally shallower structural position of the Dlhá dolina body is supported also by a high content of volatiles, which enabled its higher mobility during emplacement in the upper crust.

The most widespread ages range between 70 and $75 \mathrm{Ma}$ (KB-1 Gemeric Hnilec-Delava granite $74.7 \pm$ 5.6 Ma; KB-2 Gemeric Betliar granite $70.4 \pm 5.4 \mathrm{Ma}$; KB-3 and KB-4 from the Gemeric A-type Turčok granite $71.3 \pm 3.9 \mathrm{Ma}$ and $74.2 \pm 3.7 \mathrm{Ma}$, respectively). These may be considered as matching the cooling/exhumation trend of the footwall Veporic core complex. On the other hand, these samples were taken from localities within $15 \mathrm{~km}$ of the exocontact of the Rochovce granite, which

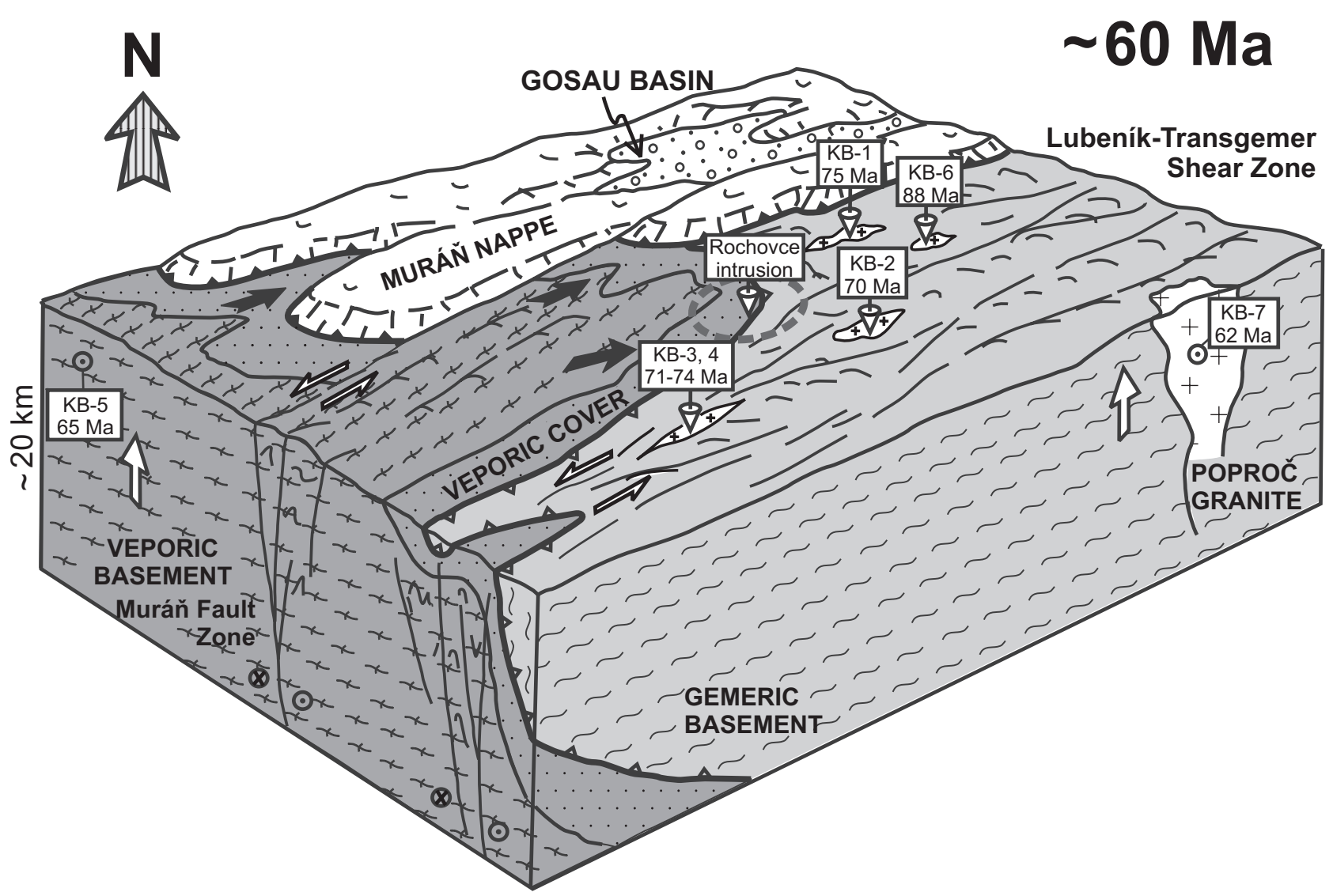

Fig. 4 Interpretative block-diagram of the Vepor-Gemer Belt at about 60 Ma before present showing approximate position of individual samples with their rounded ZFT ages and the overall tectonic regime in the area. Thick solid arrows indicate the sense of subhorizontal extensional unroofing of the Veporic core complex, paired half-arrows specify the sinistral movement within transpressional zones. The Murán nappe is a décollement cover nappe of the Silicic Superunit overlain by the Senonian sedimentary basin. The grey stippled ellipse indicates position of thermal aureole above the subsurface Rochovce granite intrusion. Shading: dark-grey for the Veporic Unit, light-grey for the Gemeric Unit; Gemeric granites, the Silicic Muráň-Stratená nappe and post-nappe Gosau cover sediments are blank. 
shows only a slightly older intrusion age (Fig. 4). Taking into account the well-developed contact aureole, these samples might have been influenced by this thermal event resulting in the observed age dispersal within individual samples. Rocks were either reheated after having cooled below the PAZ, or resided within the PAZ for a longer time during exhumation.

The Veporic Sihla granite (sample KB-5 with the central age $64.9 \pm 4.8 \mathrm{Ma}$ ) from the centre of the Veporic core complex (Fig. 4) fits well the exhumation trend. Its ZFT age is younger than any other isotopic age from the Veporic basement and yet older than the youngest AFT ages reported by Král' (1977) and Koroknai et al. (2001).

The sample KB-7 from the Gemeric Poproč granite $(61.7 \pm 3.4 \mathrm{Ma})$ comes from a remoter SE part of the Gemericum. Being aware of non-representativeness of this single datum, we suspect that this youngest obtained age may have resulted from a different tectonic regime and exhumation process in the Poproč area. This locality lies SE of the important tectonic feature of the region, the sinistral Lubeník-Transgemer Shear Zone (e.g. Grecula et al. 1990; Németh et al. 1997; Lexa et al. 2003) (Fig. 4). The latest Cretaceous/earliest Paleogene (70-60 Ma) activity of this transpressional belt was probably triggered by indentation of a rigid block from the south (Lexa et al. 2003), which likely initiated also a renewed uplift and exhumation of the SE part of the Gemeric basement sheet. The post-Senonian compressional tectonic activity in this region is revealed also by reverse faulting within the Mesozoic complexes of the Slovak Karst Mts., a few $\mathrm{km}$ south of Poproč, which incorporated also the Gosautype sediments (e.g. Mello 1997).

\section{Conclusions}

Our data are the first zircon FT ages from the Variscan basement granitoids of the Vepor-Gemer Belt in the southern part of the Central Western Carpathians. They supplement the various published thermochronological data and collectively support the current ideas about exhumation history of this area during the Late Cretaceous.

Four samples of Gemeric granites show a rather narrow span of central ZFT ages between $70.4 \pm 5.4$ and $74.7 \pm 5.6 \mathrm{Ma}$. One sample of the Gemeric granites provided an older age of $87.7 \pm 5.9 \mathrm{Ma}$, probably due to its higher structural position. One remoter sample from the SE part of the Gemericum yielded a $61.7 \pm 3.4$ Ma central ZFT age, which seems to reflect uplift and exhumation associated with a younger compressional tectonic event in that area. One sample from the centre of the Veporic metamorphic core complex indicates cooling though the zircon PAZ at $64.9 \pm 4.8 \mathrm{Ma}$.
Despite the fact that the obtained ZFT age data are rather scattered, they seem to generally follow the exhumation trend of the Veporic metamorphic core complex. Nevertheless, the cooling was apparently not uniform, particularly in the hangingwall Gemeric basement unit at the Gemeric/Veporic contact zone, where some of the measured samples were possibly affected by a thermal event caused by the Late Cretaceous Rochovce granite intrusion. This might have caused either reheating, or a protracted residence of investigated rocks within the zircon PAZ resulting in a scatter in FT ages obtained from the individual samples.

Acknowledgements This paper is a contribution to the research project DAAD-PPS "Thermal evolution and provenance of granitoid pebbles from Cretaceous flysch conglomerates of the Pieniny Klippen Belt (Western Carpathians)" and project VEGA No. 1/4039/07 funded by the Grant Agency for Science, Slovakia. Financial support from both institutions is gratefully acknowledged. Critical reviews and helpful comments by Milan Kohút and Jiří Filip as well as editorial work of Vojtěch Janoušek substantially improved an earlier version of the manuscript. We thank Wolfgang Frisch, University of Tübingen, for the technical and scientific support of this work.

\section{References}

Barbarand J, Hurford T, CArter A (2003) Variation in apatite fission-tracks length measurement: implication for thermal history modelling. Chem Geol 198: 77-106

Bibikova EV, Korikovsky SP, Putiš M, Broska I, Goltzman YV, Markov VA, Arakeliants MM (1990) U-Pb, Rb-Sr and K-Ar dating of Sihla tonalites of the Vepor Pluton (Western Carpathian Mts.). Geol Zborn Geol Carpath 41: 427-436

Broska I, Uher P (2001) Whole-rock chemistry and genetic typology of the Western-Carpathian Variscan granites. Geol Carpath 52: 79-90

Broska I, DianišKa I, Kubiš M, Uher P (2001) Spiš-Gemer granites (Slovakia) geochemistry, age and origin. In: Breiter K (ed) Phosphorus- and Fluorine-rich Fractionated Granites. Czech Geol. Survey, Prague, pp 4-5

Burchart J, CAmBel B, KráL J (1987) Isochron reassesment of $\mathrm{K}$-Ar dating from the West Carpathian crystalline complex. Geol Zborn Geol Carpath 38: 131-170

Cambel B, Bagdasaryan GP, Gukasyan R C, Veselský J (1989) Rb/Sr geochronology of leucocratic granitoid rocks from the Spišsko-Gemerské Rudohorie Mts. and Veporicum. Geol Zborn Geol Carpath 40: 323-332

Cambel B, Král J, Burchart J (1990) Isotopic Geochronology of the Western Carpathian Crystalline Complex 
with Catalogue of Data. Veda, Bratislava, pp 1-183 (in Slovak with English summary)

CARLSON WD (1990) Mechanism and kinetics of apatite fission-track annealing. Amer Miner 75: 1120-1139

Dallmeyer RD, Neubauer F, Handler R, Fritz H, Müller W, Pana D, Putiš M (1996) Tectonothermal evolution of the internal Alps and Carpathians: evidence from ${ }^{40} \mathrm{Ar} /{ }^{39} \mathrm{Ar}$ mineral and whole-rock data. Eclogae Geol Helv 89: 203-227

Dallmeyer RD, Németh Z, Putiš M (2005) Regional tectonothermal events in Gemericum and adjacent units (Western Carpathians, Slovakia). Contribution by ${ }^{40} \mathrm{Ar}{ }^{39} \mathrm{Ar}$ dating. Slovak Geol Mag 11: 155-163

Danišík M, Dunkl I, Putiš M, Frisch W, Kráe J (2004) Tertiary burial and exhumation history of basement highs along the NW margin of the Pannonian basin - an apatite fission track study. Austrian J Earth Sci 95/96: 60-70

DunkL I (2002) Trackkey: a Windows program for calculation and graphical presentation of fission track data. Comput and Geosci 28: 3-12.

FARYAD SW, DiAnIŠKA I (1989) Garnets from granitoids of the Spišsko-gemerské Rudohorie Mts. Geol Zborn Geol Carpath 49: 715-734.

Faryad SW, Henjes-Kunst F (1997) Petrological and K-Ar and ${ }^{40} \mathrm{Ar} /{ }^{39} \mathrm{Ar}$ age constraints for the tectonothermal evolution of the high-pressure Meliata unit, Western Carpathians (Slovakia). Tectonophysics 280: 141-156

Finger F, Broska I (1999) The Gemeric S-type granites in southeaster Slovakia: Late Paleozoic or Alpine intrusion? Evidence from the electron-microprobe dating of monazite. Schweitz Mineral Petrogr Mitt 79: 439-443

Fleischer RL, Price PB, WalKer RM (1975) Nuclear Tracks in Solids. California Press, Berkeley, pp 1-605

Grecula P, NÁvesŇÁk D, Bartalský B, GazdačKo L', NéMETh Z, IštvÁn J, VRbatovič P (1990) Shear zones and arc structure of Gemericum, the Western Carpathians. Miner Slov 22: 97-110

Hraško L, Határ J, Huhma H, Mäntäri I, Michalko J, VAASJOKI M (1999) U/Pb zircon dating of the Upper Cretaceous granite (Rochovce type) in the Western Carpathians. Krystalinikum 25: 163-171

HURFORD AJ (1986) Standardization of fission track dating calibration; results of questionnaire distributed by International Union of Geological Sciences Subcomission on Geochronology. Nucl Track Rad Meas 11: 329-333

HURFORD AJ (1998) ZETA: the ultimate solution to fissiontrack analysis calibration or just an interim measure. In: Van Der Haute P, De Corte F (eds) Advances in FissionTrack Geochronology. Kluwer Academic Publishers, Dordrecht, pp 19-32

HURFORD AJ, GREEN PF (1983) The zeta calibration of fission track dating. Chem Geol 80: 171-178

Janák M, Plašıenka D, Frey M, Cosca M, Schmidt ST, Lupták B, Méres Š (2001a) Cretaceous evolution of a metamorphic core complex, the Veporic unit, Western Carpathians (Slovakia) P-T conditions and in situ ${ }^{40} \mathrm{Ar} /$ ${ }^{39} \mathrm{Ar}$ UV laser probe dating of metapelites. J Metamorph Geol 19: 197-216

Janák M, Cosca M, Finger F, Plašienka D, Koroknai B, LuPTÁK B, HoRvÁth P (2001b) Alpine (Cretaceous) metamorphism in the Western Carpathians: P-T-t paths and exhumation of the Veporic core complex. Geol-Paläont Mitt Innsbruck 25: 115-118

JEŘÁBEK P. JANÁK M, FARYAD SW (2007) Low-pressure/hightemperature metamorphism of Permian age in the Vepor Unit, West Carpathians. In Venera Z (ed) CzechTec 07, Proceedings and Excursion Guide. Czech Geol. Survey, Prague, pp 39-40

KANTOR J (1960) Creataceous orogenetic processes in the frame of geochronological research of Veporic crystalline basement (Kohút belt). Geol Práce Zprávy 19: 5-26 (In Slovak)

Kissová D, Dunkl I, Plašienka D, Frisch W, Marschalko R (2005) The Pieninic exotic cordillera (Andrusov Ridge) revisited: new zircon FT ages of granite pebbles from Cretaceous conglomerates of the Pieniny Klippen Belt (Western Carpathians, Slovakia). Slovak Geol Mag 11: $17-28$

Kohút M, Stein H (1994) Re-Os molybdenite dating of granite-related Sn-W-Mo mineralisation at Hnilec, Gemeric Superunit, Slovakia. Mineral Petrol 85: 117-129

Kohút M Stein H, Radvanec M (1994) Re-Os dating of molybdenite from the Hnilec Permian granite-related mineralisation - its tectonic significance (Gemeric Unit, Slovakia). Geolines 17: 54-55

KorIKOVSKY SP, JANÁK M, BORONICHIN VA (1986) Geothermometry and mineral equilibria during recrystallization of garnet mica schists and cordierite-bearing hornfelses in the Rochovce granite aureole (Slovak Ore Mts., Rochovce-Chyžné district). Geol Zborn Geol Carpath 37: 607-633

Koroknai B, Horváth P, Balogh K, Dunkl I (2001) Alpine metamorphic evolution and cooling history of the Veporic basement in northern Hungary: new petrological and geochronological constraints. Int J Earth Sci (Geol Rundsch) 90: 740-751

Kováč M, Kráz J, Márton E, Plašienka D, Uher P (1994) Alpine uplift history of the Central Western Carpathians: geochronological, paleomagnetic, sedimentary and structural data. Geol Carpath 45: 83-96

KovÁČIK M, KRÁL J, MalusKi H (1996) Metamorphic rocks in the Southern Veporicum basement: their Alpine metamorphism and thermochronologic evolution. Miner Slov 28: 185-202 (in Slovak with English summary)

KovÁČIK M, KRÁL J, MALUSKI H (1997) Alpine reactivation of the southern Veporicum basement: metamorphism, ${ }^{40} \mathrm{Ar} /{ }^{39} \mathrm{Ar}$ dating, geodynamic model and correlation aspects with the Eastern Alps. In: Grecula P, Hovorka 
D, Putiš M (eds) Geological Evolution of the Western Carpathians. Miner Slov Monogr, pp 163-174

KováčiK M, KoneČnÝ P, Kollárová V. HolickÝ I, Siman P (2005) Electron microprobe dating of monazite in basement metamorphites from the Kohút zone of Veporicum and case correlation aspects (Western Carpathians). Slovak Geol Mag 11: 91-105.

Krác J (1977) Fission track ages of apatites from some granitoid rocks in West Carpathians. Geol Zbor Geol Carpath 28: 269-276

Král J, Frank W, Bezák V (1996) ${ }^{40} \mathrm{Ar} /{ }^{39} \mathrm{Ar}$ spectra from hornblendes of amphibolic rocks of the Veporicum. Miner Slov 28: 501-513 (in Slovak with English summary)

Krist E, Korikovsky SP, Putiš M, Janák M, Faryad SW (1992) Geology and Petrology of Metamorphic Rocks of the Western Carpathian Crystalline Complexes. Comenius Univ., Bratislava, pp 1-360

Lexa O, Schulmann K, JežeK J (2003) Cretaceous collision and indentation in the West Carpathians: view based on structural analysis and numerical modeling. Tectonics 22: 1066

Lupták B ThöNi M, JanÁK M, Petrí́ I (2004) Sm-Nd isotopic chronometry of garnets from the Veporic Unit, Western Carpathians: some preliminary age results and P-T constraints. Geolines 17: 66

Maluski H, Rajlich P, Matte Ph (1993) ${ }^{40} \mathrm{Ar}-{ }^{39} \mathrm{Ar}$ dating of the Inner Carpathian Variscan basement and Alpine mylonitic overprinting. Tectonophysics 223: 313-337

Mello J (ed) (1997) Explanations to the geological map of the Slovak Karst 1:50 000. Geol Surv Slov Rep, D. Štúr Publ, Bratislava, pp 1-255 (in Slovak with English summary)

Méres Š, Hovorka D (1991a) Geochemistry and metamorphic evolution of the Kohút Crystalline Complex mica schists (Western Carpathians). Acta Geol Geograph Univ Comen, Geol 47: 15-66

Méres Š, Hovorka D (1991b) Alpine metamorphic recrystallizalion of the pre Carboniferous metapelites of the Kohút crystalline complex (the Western Carpathians). Miner Slov 23: 435-442.

Németh Z, GazdačKo L', NÁvesŇÁk D, KobulskÝ J (1997) Polyphase tectonic evolution of the Gemericum (the Western Carpathians) outlined by review of structural and deformational data. In: Grecula P, Hovorka D, Putiš M (eds) Geological Evolution of the Western Carpathians. Miner Slov Monogr, pp 215-224

Petrík I, KoнÚt M (1997) The evolution of granitoid magmatism during the Hercynian orogen in the Western Carpathians. In: Grecula P, Hovorka D, Putiš M (eds) Geological Evolution of the Western Carpathians. Miner Slov Monogr, pp 235-252.

Petrík I, BezÁk V, HrašKo L' (1998) Granitoids of the Veporicum: a most comprehensive example of the Western
Carpathian granitoid magmatism development. In Rakús M (ed) Geodynamic Development of the Western Carpathians. Geol Surv Slov Rep, D. Štúr Publ, pp 35-45.

Plašienka D, Grecula P, Putiš M, Kováč M, Hovorka D (1997) Evolution and structure of the Western Carpathians: an overview. In: Grecula P, Hovorka D, Putiš M (eds) Geological Evolution of the Western Carpathians. Miner Slov Monogr, pp 1-24

Plašienka D, Janák M, Lupták B, Milovský R, Frey M (1999) Kinematics and metamorphism of a Cretaceous core complex: the Veporic unit of the Western Carpathians. Phys Chem Earth (A) 24: 651-658

Poller U, Uher P, JanÁk M, Plašienka D, Kohút M (2001) Late Cretaceous age of the Rochovce granite, Western Carpathians, constrained by U-Pb single-zircon dating in combination with cathodoluminescence imaging. Geol Carpath 52: 41-47

Poller U, Uher P, Broska I, Plašienka D, JanÁk M (2002) First Permian-Early Triassic zircon ages for tin-bearing granites from the Gemeric Unit (Western Carpathians, Slovakia): connection to the post-collisional extension of the Variscan orogen and S-type granite magmatism. Terra Nova 14: 41-48

PuPIN JP (1980) Zircon and granite petrology. Contrib Mineral Petrol 73: 207-220

Putiš M, Ondrejka M, Siman P, Spišiak J, Uher P, Larionov A, PAderin I (2006) First data on age of magmaticmetamorphic events of West Carpathian basement from SHRIMP dating. In: Ďurža O, Rapant S (eds) Geochémia 2006, Univ Com, Bratislava, pp 91-93

Tagami T, Galbraith RF, Yamada R, Laslett GM (1998) Revisited annealing kinetics of fission tracks in zircon and geological implications. In Van den Haute P, De Corte F (eds) Advances in Fission-track Geochronology. Kluwer Academy Publishers, Dordrecht, pp 99-112

Uher P, Broska I (1996) Post-orogenic Permian granitic rocks in the Western Carpathian-Pannonian area: geochemistry, mineralogy and evolution. Geol Carpath 47: 311-321

Uher P, GReGor T (1992) Turčok granite - product of postorogenic A-type magmatism? Miner Slov 24: 301-304 (in Slovak with English summary)

VARGA I (1973) Mineral associations and zoning of regional metamorphism in the Spišsko-Gemerské Rudohorie Mts. Miner Slov 5: 115-134 (in Russian with English summary)

VozÁRová A (1990) Development of metamorphism in the Gemeric/Veporic contact zone (Western Carpathians). Geol Zbor Geol Carpath 41: 475-502

Vozárová A, Frank W, KRÁL J (2000) ${ }^{40} \mathrm{Ar} /{ }^{39} \mathrm{Ar}$ data from contact aureole of Súl'ová granite (Gemericum, the Western Carpathians). Slovak Geol Mag 6: 363-366

VRÁNA S (1964) Chloritoid and kyanite zone of Alpine metamorphism on the boundary of the Veporides and the Gemerides. Krystalinikum 2: 125-143 
VRÁNA S (1966) Alpidische Metamorphose der Granitoide und der Foederata-Serie im Mittelteil der Veporiden. Zbor Geol Vied, Západné Karpaty 6: 29-84

VRÁNA S (1980) Newly-formed Alpine garnets in metagranitoids of the Veporides in relation to the structure of the Central zone of the West Carpathians. Cas Mineral Geol 25: 41-54

Wagner GA, VAn den Haute P (1992) Fission-track Dating. Enke, Stuttgart, pp 1-285 